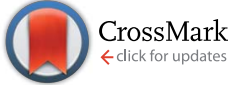

Cite this: J. Mater. Chem. A, 2015, 3, 7986

Received 3rd February 2015 Accepted 16th February 2015

DOI: $10.1039 / \mathrm{c} 5 \mathrm{ta0} 0894 \mathrm{~h}$

www.rsc.org/MaterialsA

\section{Rational design of mesoporous NiFe-alloy-based hybrids for oxygen conversion electrocatalysis $\uparrow$}

\begin{abstract}
Suqin $\mathrm{Ci}, \$$ Shun Mao, $\$$ Y Yang Hou, Shumao Cui, Haejune Kim, Ren Ren, Zhenhai Wen* and Junhong Chen*

A mesoporous NiFe-based alloy was synthesized through a hard-template technique and investigated as the electrocatalyst for oxygen evolution reaction (OER) and oxygen reduction reaction (ORR). Precious metal-free elements, i.e., nitrogen $(\mathrm{N})$, nickel ( $\mathrm{Ni})$, and iron (Fe), were merged together through either doping or alloying to form a mesoporous structure supporting NiFe-alloy electrocatalyst ( $\mathrm{m}-\mathrm{NiFe} / \mathrm{CN}_{x}$ ). The synergetic effects from multiple active sites, in combination with structural merits, endowed the $\mathrm{m}$ $\mathrm{NiFe} / \mathrm{CN}_{x}$ electrocatalyst with an excellent electrocatalytic activity for both OER and ORR, including high activity, fast kinetics, modest overpotential, and excellent stability. The $\mathrm{m}-\mathrm{NiFe} / \mathrm{CN}_{x}$ also featured a simple and scalable synthesis process with a low cost, which makes it an attractive alternative catalyst to precious metal-based electrocatalysts for OER and ORR.
\end{abstract}

\section{Introduction}

The generation of hydrogen-based renewable energy sources has become increasingly important in the search for viable alternatives to fossil fuel-based technologies in the world's renewable energy mix. ${ }^{1-7}$ The implementation of numerous sustainable energy sources is highly dependent upon oxygen electrochemistry, i.e., the oxygen evolution reaction (OER) and the oxygen reduction reaction (ORR), which are of critical importance for the mutual conversion between electrical energy and chemical energy in electrolysis cells, metal air batteries, and fuel cells. ${ }^{8-10}$ OER plays a pivotal role in water splitting and solar fuel synthesis, ${ }^{11-17}$ whereas ORR is a well-known critical process for cathodes of various fuel cells and metal-air batteries. ${ }^{18-26}$ Unfortunately, both OER and ORR proceed via multi-electron transfer with sluggish kinetics that governs the overall reaction rate. ${ }^{12,27-30}$ Moreover, Ir- and Pt-based materials, which are probably the best electrocatalysts for OER and ORR, are rare and precious substances and suffer from the drawbacks of high cost and declining activity over long-term operation, limiting their practical applications. ${ }^{31-36}$ To date, the development of bifunctional nanocatalysts for OER and ORR is still in its infancy, ${ }^{37-44}$ and there is abundant room for the exploration of novel electrocatalysts. ${ }^{45,46}$

\footnotetext{
Department of Mechanical Engineering, University of Wisconsin-Milwaukee, 3200 North Cramer Street, Milwaukee, Wisconsin 53211, United States. E-mail: wenzhenhai@yahoo.com; jhchen@uwm.edu

$\dagger$ Electronic supplementary information (ESI) available: Characterization of the reference sample and some additional electrochemical results. See DOI: $10.1039 / \mathrm{c} 5 \mathrm{ta00894h}$

\$ These authors contributed equally.
}

We herein report an alloy-based electrocatalyst for OER and ORR through a rational and elaborate design, featuring the advantages of easy preparation, low cost, enhanced reaction rate, reduced overpotential, good durability, and enhanced energy conversion efficiency. In the present strategy, mesoporous SBA-15 was selected as the catalyst support, which was decorated by nitrogen-doped (N-doped) nanocarbon that acted as the nanoreactor for the in situ growth of well-dispersed alloy nanocatalysts. Precious metal-free elements, i.e., nitrogen (N), nickel $(\mathrm{Ni})$, and iron $(\mathrm{Fe})$, were incorporated into the mesoporous structure through doping or alloying, which allowed the multiple electrocatalytic sites to synergistically contribute to both OER and ORR. In this way, the as-designed catalyst offers a smooth route for electron transfer benefitting from the improved electrical conductivity, thus leading to a high mass (ions and electrolytes) transport efficiency thanks to its mesoporous structure. Moreover, the large surface area and highly dispersed catalytic sites enable the electrocatalysts to significantly boost OER and ORR performance, which compares favorably with both Ir/C catalysts for OER and Pt/C catalysts for ORR and show much better stability than precious metal catalysts.

\section{Experimental section}

\section{Material and method}

Commercial $10 \% \mathrm{Pt}$ and $10 \%$ Ir on Vulcan XC-72 was purchased from the Fuel Cell Store (www.fuelcellstore.com). All the reagents were of analytical grade and purchased from Sigma Aldrich without further treatment. SBA-15 was synthesized according to a method mentioned in previous reports. ${ }^{47}$ In a typical synthesis of $\mathrm{m}-\mathrm{NiFe} / \mathrm{CN}_{x}, 2.0 \mathrm{~g}$ SBA-15, $2.02 \mathrm{~g}$ 
$\mathrm{FeCl}_{3} \cdot 6 \mathrm{H}_{2} \mathrm{O}((7.5 \mathrm{mM})), 1.775 \mathrm{~g} \mathrm{NiCl}_{2} \cdot 6 \mathrm{H}_{2} \mathrm{O}(7.5 \mathrm{mM})$, and $8 \mathrm{~g}$ cyanamide were added in $20 \mathrm{~mL}$ water and stirred until it was completely dry to form a tawny powder. The mixtures were heated to $750{ }^{\circ} \mathrm{C}$ at a rate of $1{ }^{\circ} \mathrm{C} \mathrm{min}{ }^{-1}$ and maintained at that temperature for 1 hour under an Ar atmosphere. The reference samples, i.e. $\mathrm{NiFe} / \mathrm{CN}_{x}, \mathrm{~m}-\mathrm{Ni} / \mathrm{CN}_{x}$, and $\mathrm{m}-\mathrm{Fe} / \mathrm{CN}_{x}$, were prepared through a similar method to $\mathrm{m}-\mathrm{NiFe} / \mathrm{CN}_{x}$, but without adding SBA-15, or $\mathrm{FeCl}_{3} \cdot 6 \mathrm{H}_{2} \mathrm{O}$, or $\mathrm{NiCl}_{2} \cdot 6 \mathrm{H}_{2} \mathrm{O}$, respectively.

\section{Characterization}

The morphology and nanostructures of the samples were obtained using a Hitachi (H 9000 NAR) transmission electron microscope (TEM) and a Hitachi (S-4800) scanning electron microscope (SEM) equipped with an energy-dispersive spectroscopy analyzer. The X-ray powder diffraction (XRD) patterns were tested in a Scintag XDS $2000 \mathrm{X}$-ray powder diffractometer with monochromatized CuK $\alpha$ radiation $(\lambda=1.5418 \AA)$. X-ray photoelectron spectroscopy (XPS) was conducted using an HP 5950A ESCA spectrometer with $\mathrm{Mg} \mathrm{K} \alpha$ as the source and the $\mathrm{C} 1 \mathrm{~s}$ peak at $284.6 \mathrm{eV}$ as an internal standard. Specific surface areas were measured by Brunauer-Emmett-Teller (BET) nitrogen adsorption-desorption using a Quantachrome Autosorb gassorption system.

\section{Electrochemical measurement}

The catalyst suspension was prepared as follows: $3.0 \mathrm{mg}$ electrode material (m-NiFe/CN $\mathrm{CN}_{x}, \mathrm{NiFe} / \mathrm{CN}_{x}, \mathrm{~m}-\mathrm{Ni} / \mathrm{CN}_{x}, \mathrm{~m}-\mathrm{Fe} / \mathrm{CN}_{x}, \mathrm{Ir} /$ $\mathrm{C}$ or $\mathrm{Pt} / \mathrm{C}$ ) was dispersed in a mixture of $0.05 \mathrm{~mL}$ Nafion and 0.45 $\mathrm{mL}$ distilled water through ultrasonic agitation for 5 minutes. The working electrode, i.e., glassy carbon electrode (GCE, $\varphi: 3.0$ $\mathrm{mm}$ ) and rotating disk electrode (RDE), were first polished using aluminum oxide $\left(\mathrm{Al}_{2} \mathrm{O}_{3}, 1 \mu \mathrm{m}\right.$ and $\left.0.3 \mu \mathrm{m}\right)$ powder followed by rinsing thoroughly with distilled water. After successive sonication in deionized water and ethanol, the electrode was rinsed with double distilled water and dried at room temperature. The working electrode was prepared by dropping $6 \mu \mathrm{L}$ of catalyst ink on the glassy carbon electrode and drying it at room temperature.

\section{OER test}

The electrocatalytic activity for OER was measured with a threeelectrode system using a bipotentiostat (CHI760D, CHI Instrument), in which a platinum wire and a saturated $\mathrm{Ag} / \mathrm{AgCl}$ electrode were used as the counter electrode and the reference electrode, respectively. RRDE measurements were conducted in an argon-saturated $\mathrm{KOH}$ solution $(0.1 \mathrm{M})$ at a scan rate of $5 \mathrm{mV} \mathrm{s}^{-1}$ and a rotation speed of $1600 \mathrm{rpm}$ (RDE-3A Rotating Ring Disk Electrode Apparatus Ver.1.2, ALS Co., Ltd). The Pt ring was treated by cycling between 0 and $1.2 \mathrm{~V}$ in $0.5 \mathrm{M} \mathrm{H}_{2} \mathrm{SO}_{4}$ for 10 cycles before performing RRDE experiments. The potential on the Pt ring electrode was set to $0.6 \mathrm{~V}$ and $1.5 \mathrm{~V}$ for monitoring the products produced at the disk electrode.

\section{ORR test}

Electrochemical measurements for ORR were also performed on the same electrochemical instrument using a three-electrode system, in which the modified electrode was used as the working electrode, a platinum wire was used as the counter electrode, and a saturated $\mathrm{Ag} / \mathrm{AgCl}$ electrode was used as the reference electrode. The supporting electrolyte was a $0.1 \mathrm{M} \mathrm{KOH}$ solution. Cyclic voltammetry (CV) was carried out at a scan rate of $50 \mathrm{mV} \mathrm{s}^{-1}$. The polarization curves for ORR were obtained through RDE and RRDE techniques at a scan rate of $5 \mathrm{mV} \mathrm{s}^{-1}$, and the current was normalized to surface the area of the electrode. Linear sweep voltammetry (LSV) was performed at a scan rate of $5 \mathrm{mV} \mathrm{s}^{-1}$ with varying rotating speed from $400 \mathrm{rpm}$ to $2500 \mathrm{rpm}$ for the ORR measurements. Experiments for OER were conducted by rotating the working electrode continuously at $1600 \mathrm{rpm}$.

\section{Rotating ring-disk electrode (RRDE) measurements}

The disk electrode was scanned at a rate of $5 \mathrm{mV} \mathrm{s}^{-1}$, and the ring potential was constantly set at $1.5 \mathrm{~V} v s$. RHE. The electron transfer number $(n)$ and the hydrogen peroxide yield $\left(\% \mathrm{H}_{2} \mathrm{O}_{2}\right)$ were determined by the following two equations:

$$
\begin{gathered}
n=4 I_{\mathrm{d}} /\left(I_{\mathrm{d}}+I_{\mathrm{r}} / N\right) \\
\% \mathrm{H}_{2} \mathrm{O}_{2}=200 I_{\mathrm{r}} /\left(N I_{\mathrm{d}}+I_{\mathrm{r}}\right)
\end{gathered}
$$

where $I_{\mathrm{d}}$ is the disk current, $I_{\mathrm{r}}$ is the ring current and $N$ is the collection efficiency of the ring electrode, which was determined to be 0.42 from the reduction of $\mathrm{K}_{3} \mathrm{Fe}[\mathrm{CN}]_{6}$.

\section{Electrochemical impedance spectroscopy (EIS) measurements}

EIS tests were conducted at $1.5 \mathrm{~V} v s$. RHE in a frequency range of $100 \mathrm{kHz}$ to $50 \mathrm{mHz}$. The data were plotted in a Nyquist curve; charge transfer resistance $\left(R_{\mathrm{ct}}\right)$ was determined by fitting the measured impedance data to an equivalent circuit.

\section{RHE calibration}

An $\mathrm{Ag} / \mathrm{AgCl}$ electrode (saturated $\mathrm{KCl}$ ) was used as the reference electrode in all the measurements. The measured potentials were converted to the reversible hydrogen electrode (RHE) via the Nernst equation:

$$
E_{\mathrm{RHE}}=E_{\mathrm{Ag} / \mathrm{AgCl}}+0.059 \mathrm{pH}+E_{\mathrm{Ag} / \mathrm{AgCl}}^{0}
$$

where $E_{\mathrm{RHE}}$ is the converted potential versus $\mathrm{RHE}, E_{\mathrm{Ag} / \mathrm{AgCl}}$ is the experimental potential measured against the $\mathrm{Ag} / \mathrm{AgCl}$ reference electrode, and $E_{\mathrm{Ag} / \mathrm{AgCl}}^{0}$ is the standard potential of $\mathrm{Ag} / \mathrm{AgCl}$ at $25{ }^{\circ} \mathrm{C}(0.1976 \mathrm{~V})$. The electrochemical measurements were carried out in $0.1 \mathrm{M} \mathrm{KOH}(\mathrm{pH}=13)$ at room temperature; therefore, the $E_{\mathrm{RHE}}=E_{\mathrm{Ag} / \mathrm{AgCl}}+0.9649 \mathrm{~V}$.

\section{Results and discussion}

An electrocatalyst, i.e., a nitrogen-doped nanocarbon modified SBA-15 supported NiFe-alloy $\left(\mathrm{m}-\mathrm{NiFe} / \mathrm{CN}_{x}\right)$, was synthesized by a 
simple method (Fig. 1a). The process started with thoroughly mixing cyanamide, $\mathrm{SBA}-15, \mathrm{FeCl}_{3}$, and $\mathrm{NiCl}_{2}$ in an aqueous solution followed by stirring them until the mixture completely dried. The dried powder was then heated to $750{ }^{\circ} \mathrm{C}$ under an argon environment. The cyanamide was initially polymerized to form carbon nitride polymer in the nanochannels of SBA-15 and then slowly decomposed to generate carbon- and nitrogencontaining gases (e.g., $\mathrm{C}_{2} \mathrm{~N}_{2}{ }^{+}$and $\mathrm{C}_{3} \mathrm{~N}_{2}{ }^{+}$), ${ }^{48-51}$ which reacted with $\mathrm{Ni}$ and $\mathrm{Fe}$ sources to produce $\mathrm{Ni}, \mathrm{Fe}$, and NiFe-alloy nanoparticles in the mesopores. These Ni or Fe nanoparticles then functioned as catalysts for the in situ growth of N-doped nanocarbon decorated SBA-15.

Scanning electron microscopy (SEM) was carried out to study the morphology of the as-synthesized catalyst. The SEM image of the $\mathrm{m}-\mathrm{NiFe} / \mathrm{CN}_{x}$ shows a well-defined shape and morphology decorated with plenty of carbon nanostructures (Fig. 1b); in contrast, the pristine SBA-15 shows a blurry and distorted SEM image due to poor electrical conductivity (Fig. S1†), suggesting the electrical conductivity was significantly improved in the $\mathrm{m}$ $\mathrm{NiFe} / \mathrm{CN}_{x}$ compared with SBA-15. Fig. 1c shows the transmission electron microscopy (TEM) image of the $\mathrm{m}-\mathrm{NiFe} / \mathrm{CN}_{x}$, also confirming that carbon nanofibers stick out from the samples (Fig. 1c). The magnified TEM images indicate that lots of nanoparticles are dispersed in the porous channels of the $\mathrm{m}$ $\mathrm{NiFe} / \mathrm{CN}_{x}$ samples (Fig. 1d), and a film of carbon modifies the $\mathrm{m}-\mathrm{NiFe} / \mathrm{CN}_{x}$ samples (Fig. 1e-g). According to high-resolution TEM (HRTEM) images from different regions (Fig. 2), the m$\mathrm{NiFe} / \mathrm{CN}_{x}$ maintains an ordered porous structure of SBA-15 with a channel size of around $6.0 \mathrm{~nm}$; these channels can provide enough space for electrolyte or ion transport. In addition, there are many nanoparticles dispersed in the porous channels. Further analyses indicate that the nanoparticles have a lattice spacing of around $0.21 \mathrm{~nm}$ (Fig. $1 \mathrm{~g}$ and $2 \mathrm{c}$ and $\mathrm{d}$ ), corresponding with the (111) crystalline planes of the NiFe alloy, suggesting that these nanoparticles are NiFe alloy nanoparticles. In addition, the well-defined graphite crystal structure

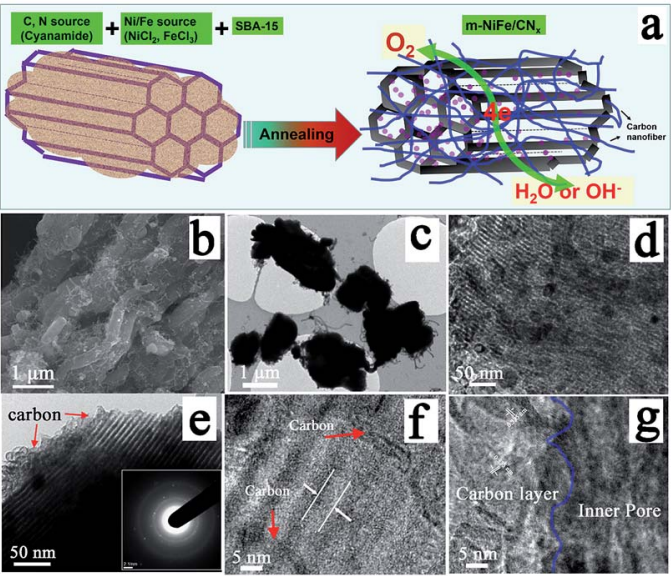

Fig. 1 (a) Schematic for the synthesis of the $\mathrm{m}-\mathrm{NiFe} / \mathrm{CN}_{x}$ hybrid; (b) SEM image, and (c-g) TEM images of the $\mathrm{m}-\mathrm{NiFe} / \mathrm{CN}_{x}$ hybrid with various magnifications from different regions; inset in $(e)$ is the corresponding SAED pattern.

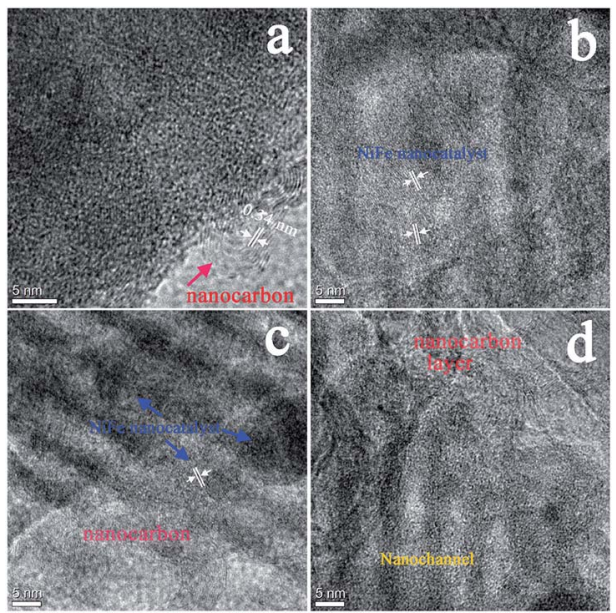

Fig. 2 HRTEM images of the as-prepared $m-\mathrm{NiFe} / \mathrm{CN}_{x}$ from different regions.

with an interlayer $d$-spacing of $\sim 0.34 \mathrm{~nm}$ was either sparsely dispersed through or compactly decorated around SBA-15.

According to the powder X-ray diffraction (XRD) patterns (Fig. 3a), two peaks assigned to (002) and (101) planes of graphite carbon can be observed at about $26.1^{\circ}$ and $44.3^{\circ}$, two strong peaks at $43.5^{\circ}$ and $50.8^{\circ}$ indicate that the dominant products are NiFe alloy (JCPDS no. 23-0297), and the left side peaks can be assigned to the characteristic peaks of iron carbide. Based on nitrogen adsorption-desorption measurements, it can be inferred that the $\mathrm{m}-\mathrm{NiFe} / \mathrm{CN}_{x}$ has a BrunauerEmmett-Teller (BET) surface area of $246.9 \mathrm{~m}^{2} \mathrm{~g}^{-1}$, a pore volume of $0.39 \mathrm{~cm}^{3} \mathrm{~g}^{-1}$, and an average pore size of $\sim 6.1 \mathrm{~nm}$ (Fig. 3b); this value is larger than that of $\mathrm{NiFe} / \mathrm{CN}_{x}$. The energydispersive X-ray spectroscopy (EDS) map further verified the distributions and intensities of Ni, Fe, N, C, Si, and O elements that match well with the SEM image of the $\mathrm{m}-\mathrm{NiFe} / \mathrm{CN}_{x}$ (Fig. 4). A series of peaks corresponding to $\mathrm{C}, \mathrm{N}, \mathrm{Fe}, \mathrm{Ni}$, and $\mathrm{O}$ are found in the survey X-ray photoelectron spectrum (XPS), reconfirming the existence of these elements in $\mathrm{m}-\mathrm{NiFe} / \mathrm{CN}_{x}$ (Fig. 5a). The high resolution peak of $\mathrm{N} 1 \mathrm{~s}$ (Fig. 5c) can be fitted to pyridinetype nitrogen (398.2 eV), pyrrolic-type $\mathrm{N}$ doping (399.9 eV), graphite-type nitrogen $(401.2 \mathrm{eV})$, and pyridine $\mathrm{N}$-oxide $(402.1 \mathrm{eV})$. In addition, two principal peaks in the $\mathrm{Ni} 2 \mathrm{p} 3 / 2$ spectrum centered at 854.3 and $855.6 \mathrm{eV}$ could be attributed to the alloy-state and oxide-state of Ni (Fig. 5d), while the Fe 2p3/2
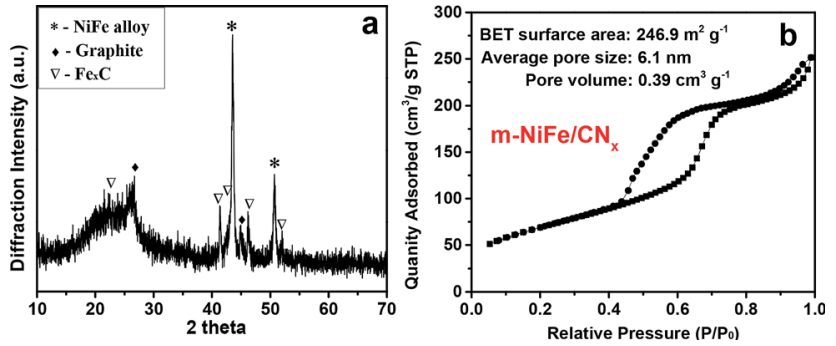

Fig. 3 (a) XRD pattern and (b) $\mathrm{N}_{2}$ adsorption-desorption isothermal curve of the as-prepared $\mathrm{m}-\mathrm{NiFe} / \mathrm{CN}_{x}$. 


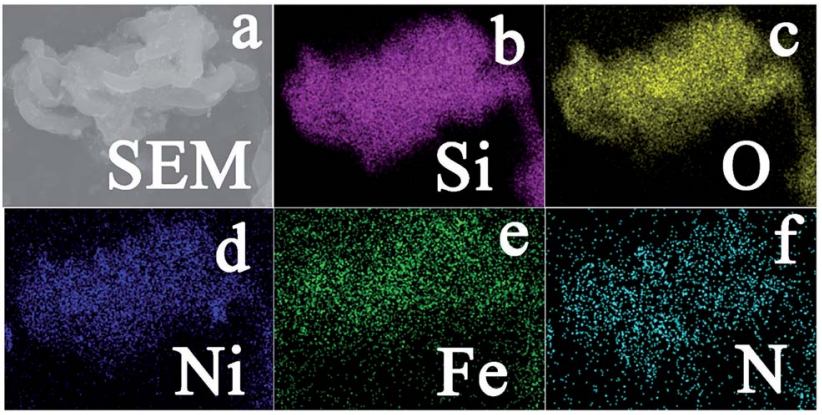

Fig. 4 (a) SEM image of the as-prepared $\mathrm{m}$-NiFe/ $\mathrm{CN}_{x}$; and $\mathrm{X}$-ray elemental mapping of (b) $\mathrm{Si}$, (c) $\mathrm{O}$, (d) $\mathrm{Ni}$, (e) $\mathrm{Fe}$, and (N) for the $\mathrm{m}-\mathrm{NiFe} / \mathrm{CN}_{x}$
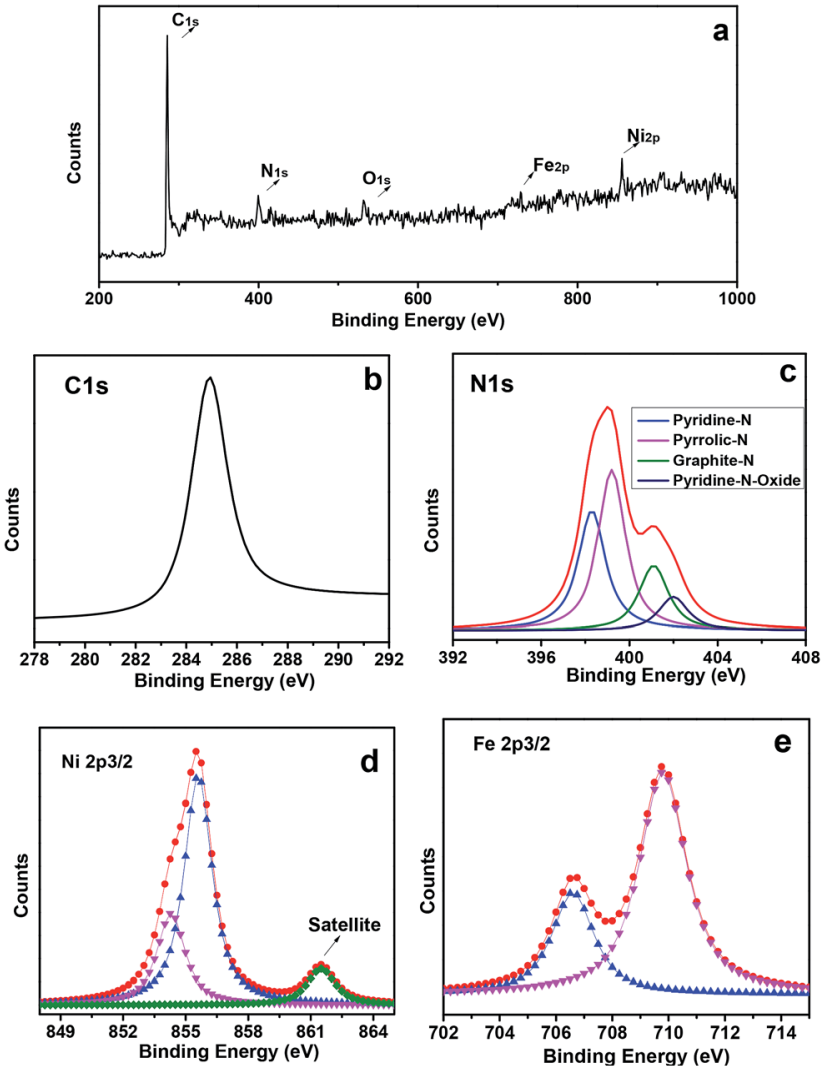

Fig. 5 (a) Survey XPS spectrum of the $\mathrm{m}-\mathrm{NiFe} / \mathrm{CN}_{x}$ (b) high resolution XPS spectra of the C 1s, (c) N 1s, (d) Ni 2p3/2, and (e) Fe 2p3/2 in m$\mathrm{NiFe} / \mathrm{CN}_{x}$ after Shirley background removal.

signals at about 706.5 and $710.3 \mathrm{eV}$ can be assigned to alloy Fe and $\mathrm{Fe}-\mathrm{O}$ bonds (Fig. 5e), respectively. It should be noted that the samples produced without adding SBA-15, i.e., $\mathrm{NiFe} / \mathrm{CN}_{x}$, are NiFe-carbon core-shell microspheres with a size of around $1.0 \mu \mathrm{m}$ (Fig. 6), suggesting that the pores of SBA-15 served as nanoreactors for the formation of nanocatalysts.

The electrochemical catalytic properties of OER were measured by linear scan voltammogram (LSV) for a set of materials, including m-NiFe/CN $\mathrm{CN}_{x}, \mathrm{NiFe} / \mathrm{CN}_{x}, \mathrm{~m}-\mathrm{Ni} / \mathrm{CN}_{x}$ (Fig. S2a and $\mathrm{b} \dagger$ ), $\mathrm{m}-\mathrm{Fe} / \mathrm{CN}_{x}$ (Fig. S2c and $\mathrm{d} \dagger$ ), and commercial $\mathrm{Ir} / \mathrm{C}$,

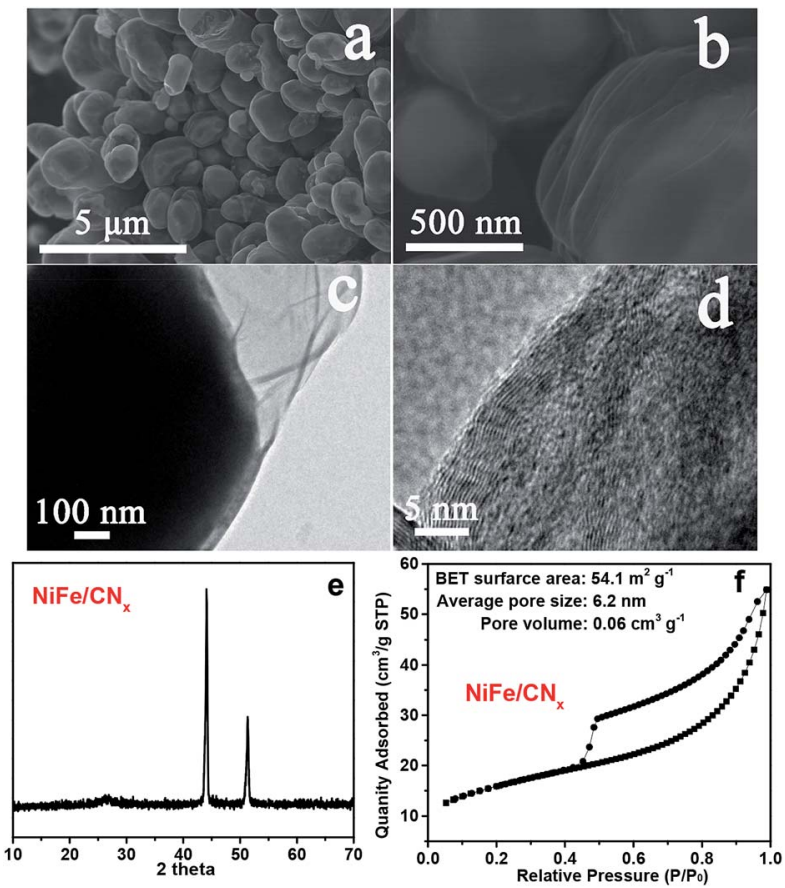

Fig. 6 (a and b) SEM images, (c and d) TEM images, (e) XRD pattern, and (f) $\mathrm{N}_{2}$ adsorption-desorption isothermal curve of the $\mathrm{NiFe} / \mathrm{CN}_{x}$.

which were either purchased or prepared by our group. As shown in Fig. 7a, the anodic current recorded with the m-NiFe/ $\mathrm{CN}_{x}$ showed an onset OER potential at $\sim 1.45 \mathrm{~V}$ ( $v s$. RHE) with an overpotential $(\eta)$ of $0.22 \mathrm{~V}$. The onset potential was significantly lower than those of the $\mathrm{m}-\mathrm{Ni} / \mathrm{CN}_{x}, \mathrm{~m}-\mathrm{Fe} / \mathrm{CN}_{x}$, and $\mathrm{NiFe} / \mathrm{CN}_{x}$ samples, whose corresponding onset potentials (overpotentials) were found to be $\sim 1.56(\eta=0.33 \mathrm{~V}), 1.67 \mathrm{~V}(\eta=0.44 \mathrm{~V})$, and $\sim 1.52(\eta=0.29 \mathrm{~V})$, respectively. Notably, the overpotential of the $\mathrm{m}-\mathrm{NiFe} / \mathrm{CN}_{x}$ electrode was even smaller than that of the $\mathrm{Ir} / \mathrm{C}$ catalyst, which showed an onset potential at $\sim 1.50 \mathrm{~V}(\eta=0.27 \mathrm{~V})$. The $\mathrm{m}-\mathrm{NiFe} / \mathrm{CN}_{x}$ also showed better electrocatalytic performance than the porous $\mathrm{Fe}_{2} \mathrm{O}_{3}$ (Fig. $\mathrm{S} 3 \mathrm{a}$ and $\mathrm{b} \dagger$ ), porous $\mathrm{NiO}$ (Fig. $\mathrm{S} 3 \mathrm{c}$ and $\mathrm{d} \dagger$ ), and $\mathrm{C}_{3} \mathrm{~N}_{4}$ samples, as shown by a remarkably higher current density, a significantly lower overpotential and a smaller Tafel slope (Fig. S4†).

The catalytic activities for OER were further evaluated by the overpotential required to achieve an OER current density of $10 \mathrm{~mA} \mathrm{~cm}{ }^{-2}$, a commonly-used criterion for evaluating OER catalysts. $^{13,37}$ The $\mathrm{m}-\mathrm{NiFe} / \mathrm{CN}_{x}$ obtained a current density of $10 \mathrm{~mA} \mathrm{~cm}{ }^{-2}$ at $1.59 \mathrm{~V}$ (Fig. 7a). In contrast, the $\mathrm{m}-\mathrm{Ni} / \mathrm{CN}_{x}, \mathrm{~m}-\mathrm{Fe} /$ $\mathrm{CN}_{x}$, porous $\mathrm{NiO}$, and $\mathrm{NiFe} / \mathrm{CN}_{x}$ samples showed a current density of $10 \mathrm{~mA} \mathrm{~cm}^{-2}$ until the potential reached $\sim 1.70, \sim 1.88$, $\sim 2.0$, and $\sim 1.75 \mathrm{~V}$, respectively. The porous $\mathrm{Fe}_{3} \mathrm{O}_{4}$ and the g$\mathrm{C}_{3} \mathrm{~N}_{4}$ showed negligible OER activities over the potential range investigated. As expected, the $\mathrm{m}-\mathrm{NiFe} / \mathrm{CN}_{x}$ also showed a higher catalytic activity than the $\mathrm{Ir} / \mathrm{C}$ catalysts, which generated a current density of $10 \mathrm{~mA} \mathrm{~cm} \mathrm{~cm}^{-2}$ at $1.65 \mathrm{~V}$. Tafel curves were plotted from the corresponding OER polarization curves, as shown in Fig. 7b. The $\mathrm{m}-\mathrm{NiFe} / \mathrm{CN}_{x}$ showed a Tafel slope of 59.1 $\mathrm{mV} \mathrm{dec}^{-1}$; this value is slightly smaller than that of the $\mathrm{Ir} / \mathrm{C}$ (61.5 $\mathrm{mV} \mathrm{dec}^{-1}$ ) and is considerably smaller than those of $\mathrm{m}-\mathrm{Ni} / \mathrm{CN}_{x}$ 

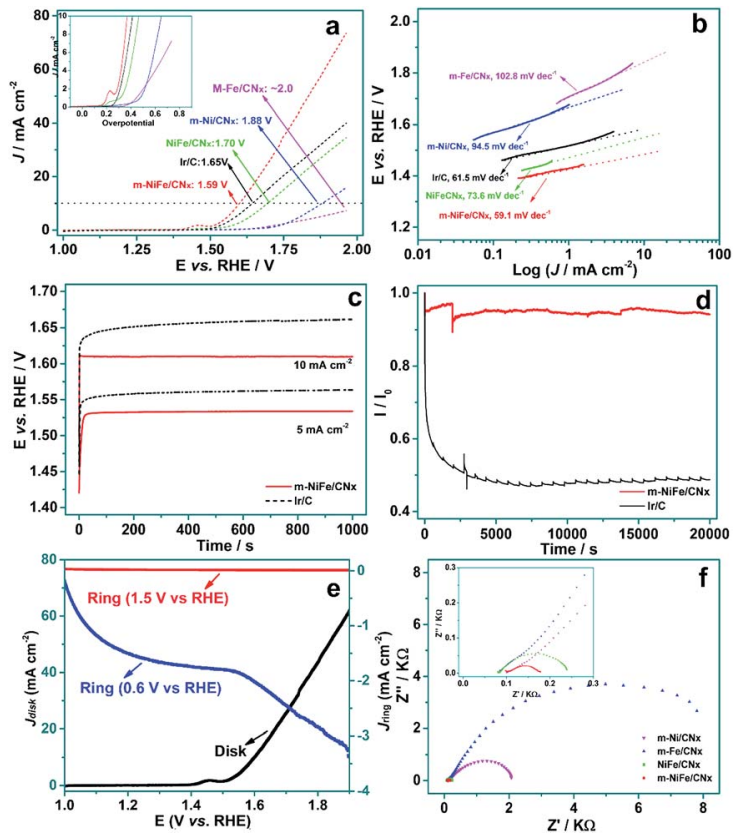

Fig. 7 (a) Rotating disk voltammograms and the corresponding data re-plotted as the current density vs. overpotential (inset) in $\mathrm{O}_{2}$-saturated $0.1 \mathrm{M} \mathrm{KOH}$ at a scan rate of $5 \mathrm{mV} \mathrm{s}^{-1}$ and $1600 \mathrm{rpm}$; (b) the corresponding Tafel plots at $\mathrm{m}-\mathrm{NiFe} / \mathrm{CN}_{x}, \mathrm{~m}-\mathrm{Ni} / \mathrm{CN}_{x}, \mathrm{~m}-\mathrm{Fe} / \mathrm{CN}_{x}, \mathrm{NiFe} /$ $\mathrm{CN}_{x}$ and $\mathrm{m}-\mathrm{Ir} / \mathrm{C}$ modified electrode; (c) chronopotentiometry curves of $\mathrm{m}-\mathrm{NiFe} / \mathrm{CN}_{x}$ and $\mathrm{Ir} / \mathrm{C}$ catalyst electrodes at a constant current density of 5 and $10 \mathrm{~mA} \mathrm{~cm}^{-2}$; (d) chronoamperometric response of the $\mathrm{m}-\mathrm{NiFe} / \mathrm{CN}_{x}$ and Ir/C catalysts at $1.6 \mathrm{~V}$ vs. RHE; (e) RRDE measurements of ring current density recorded at the platinum ring electrode maintained at $1.5 \mathrm{~V}$ or $0.6 \mathrm{~V}$ (vs. RHE) in an Ar-saturated $0.1 \mathrm{M} \mathrm{KOH}$ solution and disc current density at the $\mathrm{m}-\mathrm{NiFe} / \mathrm{CN}_{x}$ disc electrode, rotation speed: $1600 \mathrm{rpm}$, scan rate: $5 \mathrm{mV} \mathrm{s}^{-1}$; (f) Nyquist curves recorded at the $\mathrm{m}-\mathrm{NiFe} / \mathrm{CN}_{x}, \mathrm{~m}-\mathrm{Ni} / \mathrm{CN}_{x}, \mathrm{~m}-\mathrm{Fe} / \mathrm{CN}_{x}$, and $\mathrm{NiFe} / \mathrm{CN}$ modified electrodes upon catalyzing OER. The inset shows an amplified Nyquist curve at the high frequency.

(94.5 mV dec $\left.{ }^{-1}\right), \mathrm{m}-\mathrm{Fe} / \mathrm{CN}_{x}\left(102.8 \mathrm{mV} \mathrm{dec}{ }^{-1}\right), \mathrm{NiFe} / \mathrm{CN}_{x}(73.6 \mathrm{mV}$ $\left.\mathrm{dec}^{-1}\right)$, $\mathrm{NiO}\left(97.5 \mathrm{mV} \mathrm{dec}{ }^{-1}\right), \mathrm{Fe}_{3} \mathrm{O}_{4}\left(104.5 \mathrm{mV} \mathrm{dec}{ }^{-1}\right)$, and $\mathrm{C}_{3} \mathrm{~N}_{4}$ $\left(130.6 \mathrm{mV} \mathrm{dec}^{-1}\right)$. The lower overpotential, higher current density, and smaller Tafel slope of the m-NiFe/ $\mathrm{CN}_{x}$ indicate significantly improved catalytic activity and enhanced kinetics for OER.

The $\mathrm{m}-\mathrm{NiFe} / \mathrm{CN}_{x}$ catalyst also shows higher activity and better durability upon long-term OER operation compared with the Ir/C electrocatalyst. As shown in Fig. 7c, when galvanostatically biased at $10 \mathrm{~mA} \mathrm{~cm}{ }^{-2}$, the $\mathrm{m}-\mathrm{NiFe} / \mathrm{CN}_{x}$ hybrid maintained a constant operating potential at $\sim 1.61 \mathrm{~V}$ after running for 1000 seconds, whereas the $\mathrm{Ir} / \mathrm{C}$ catalyst showed an observable increase in overpotential by $\sim 20 \mathrm{mV}$. When operated galvanostatically at a current density of $5 \mathrm{~mA} \mathrm{~cm}{ }^{-2}$, the working potential remained at $\sim 1.53 \mathrm{~V}$ for the $\mathrm{m}-\mathrm{NiFe} / \mathrm{CN}_{x}$, which also showed a smaller overpotential than the $\mathrm{Ir} / \mathrm{C}$ catalyst. The durability of the m-NiFe/ $\mathrm{CN}_{x}$ hybrid and the Ir/C catalyst were also assessed through chronoamperometric measurements at $1.6 \mathrm{~V}$ vs. RHE (Fig. 7d). The current density of $\mathrm{m}-\mathrm{NiFe} / \mathrm{CN}_{x}$ was nearly twice that of Ir/C, further confirming a higher OER catalytic activity of the m-NiFe/ $\mathrm{CN}_{x}$ than that of the commercial Ir/C. Moreover, the current of the $\mathrm{m}-\mathrm{NiFe} / \mathrm{CN}_{x}$ was maintained more than $90 \%$ of the initial current during the $20000 \mathrm{~s}$ test whereas the Ir/C lost nearly $50 \%$ of its initial current density. Rotating ring-disk electrode (RRDE) voltammograms were further conducted by applying a given voltage at the platinum ring electrode upon scanning from 1.0 to $1.9 \mathrm{~V}$ ( $v s$. RHE) at the disk electrode. In this way, we were able to monitor the intermediate products produced in the disk electrode during the scanning. In particular, the ring potential was set as $0.6 \mathrm{~V}$ to detect the $\mathrm{O}_{2}$ reduction and $1.5 \mathrm{~V}$ to measure $\mathrm{H}_{2} \mathrm{O}_{2}$ oxidation. As shown in Fig. 7e, almost no oxidation current was observed on the ring electrode when it was set at $1.5 \mathrm{~V}$ during the scanning, suggesting that there was negligible $\mathrm{H}_{2} \mathrm{O}_{2}$ formed in this process. In contrast, an apparent reduction current was observed starting at around $1.5 \mathrm{~V}$ due to the evolution of oxygen when $0.6 \mathrm{~V}$ was applied at the ring electrode. These results demonstrated that the $\mathrm{m}-\mathrm{NiFe} / \mathrm{CN}_{x}$ catalyzed water oxidation through a four-electron route with the evolution of $\mathrm{O}_{2}$. Furthermore, electrical impedance spectroscopy (EIS) tests demonstrated that the m-NiFe/ $\mathrm{CN}_{x}$ hybrid had the lowest charge transfer resistance among these electrocatalysts when it catalyzed the OER (Fig. 7f).

The m-NiFe/ $\mathrm{CN}_{x}$ also shows an outstanding electrocatalytic activity for ORR. Fig. 8a shows cyclic voltammograms (CV) obtained from different electrodes. The porous NiO, porous $\mathrm{Fe}_{2} \mathrm{O}_{3}, \mathrm{C}_{3} \mathrm{~N}_{4}$, and $\mathrm{m}-\mathrm{Ni} / \mathrm{CN}_{x}$ samples showed an onset potential below $0.7 \mathrm{~V}$ ( $v s$. RHE) and displayed a quite low current density $\left(<2 \mathrm{~mA} \mathrm{~cm}{ }^{-2}\right.$ ), while the $\mathrm{m}-\mathrm{Fe} / \mathrm{CN}_{x}$ and $\mathrm{NiFe} / \mathrm{CN}_{x}$ exhibited a distinct positive shift to $\sim 0.88 \mathrm{~V}$ and $\sim 0.86 \mathrm{~V}$ ( $v s$. RHE) in onset potential and an improved limiting current density of $\sim 3.2 \mathrm{~mA}$ $\mathrm{cm}^{-2}$ and $\sim 4.3 \mathrm{~mA} \mathrm{~cm}{ }^{-2}$, respectively. Notably, the $\mathrm{m}-\mathrm{NiFe} / \mathrm{CN}_{x}$ manifested an onset potential of $0.91 \mathrm{~V}(v s$. RHE) and a limiting current density of $6.3 \mathrm{~mA} \mathrm{~cm}{ }^{-2}$. The more positive onset potential, which is associated with a higher limiting current density, provides solid evidence that the $\mathrm{m}-\mathrm{NiFe} / \mathrm{CN}_{x}$ possessed a higher catalytic activity than its counterparts (Fig. S5†).

To better understand the catalytic properties of the catalysts for ORR, the rotating-disk linear sweep voltammograms were conducted by scanning the potential from 1.2 to $0.3 \mathrm{~V}$ at different rotation rates (Fig. $8 \mathrm{~b}$ and $\mathrm{S} 6 \dagger$ ). The three samples, i.e., $\mathrm{m}-\mathrm{Ni} / \mathrm{CN}_{x}, \mathrm{~m}-\mathrm{Fe} / \mathrm{CN}_{x}$, and $\mathrm{C}_{3} \mathrm{~N}_{4}$, showed an increasing limiting current density rather than a steady-state limiting current density, suggesting that the ORR went through a multi-step process with $\mathrm{H}_{2} \mathrm{O}_{2}$ intermediates in these electrodes. In contrast, the $\mathrm{m}-\mathrm{NiFe} / \mathrm{CN}_{x}$ exhibited a stable limiting current density, indicating that the ORR predominantly proceeded through a one-step reaction pathway to produce water for the $\mathrm{m}$ $\mathrm{NiFe} / \mathrm{CN}_{x}$ electrode. It should be noted that the $\mathrm{NiFe} / \mathrm{CN}_{x}$ can also obtain a stable limiting current density; however, the limiting current density at the $\mathrm{m}-\mathrm{NiFe} / \mathrm{CN}_{x}$ electrode is 1.5 times higher than that of $\mathrm{NiFe} / \mathrm{CN}_{x}$.

To verify the ORR catalytic pathways of the $\mathrm{m}-\mathrm{NiFe} / \mathrm{CN}_{x}$, we performed RRDE measurements to monitor the formation of peroxide species $\left(\mathrm{HO}_{2}{ }^{-}\right)$and to estimate the number of electrons transferred during the ORR process. Fig. 8c shows the ring current density $\left(I_{\mathrm{r}}\right)$ and disk current density $\left(I_{\mathrm{d}}\right)$ upon cathodic scanning. A very small $I_{\mathrm{r}}$ was detected with the potential scanning to the ORR region $(0.20-0.80 \mathrm{~V})$, suggesting only a small 

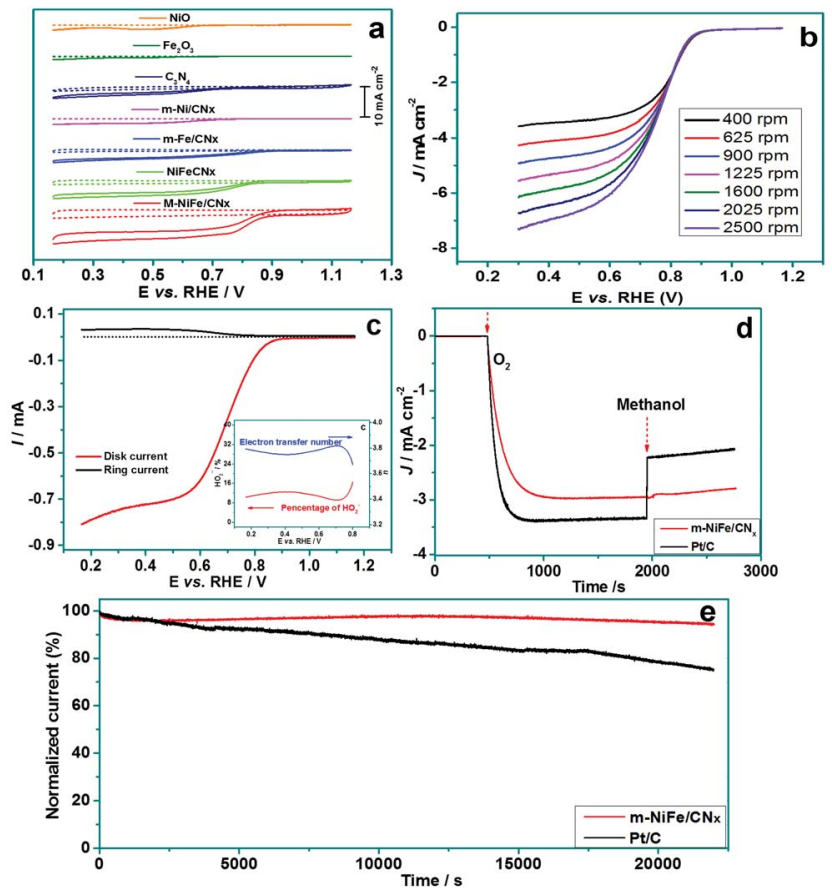

Fig. 8 (a) $\mathrm{CV}$ curves of $\mathrm{NiO}, \mathrm{Fe}_{3} \mathrm{O}_{4}, \mathrm{C}_{3} \mathrm{~N}_{4}, \mathrm{~m}-\mathrm{NiFe} / \mathrm{CN}_{x}, \mathrm{~m}-\mathrm{Ni} / \mathrm{CN}_{x}, \mathrm{~m}-$ $\mathrm{Fe} / \mathrm{CN}_{x}$, and $\mathrm{NiFe} / \mathrm{CN}_{x}$ on GCE in Ar-saturated (dash line) or $\mathrm{O}_{2}-$ saturated (solid line) $0.1 \mathrm{M} \mathrm{KOH}$ with a sweep rate of $50 \mathrm{mV} \mathrm{s}^{-1}$ and a rotation speed of $1600 \mathrm{rpm}$; (b) the RDE voltammogram plots in $\mathrm{O}_{2}$ saturated $0.1 \mathrm{M} \mathrm{KOH}$ with a sweep rate of $5 \mathrm{mV} \mathrm{s}^{-1}$ at different rotation rates; (c) RRDE voltammograms recorded at the $\mathrm{m}-\mathrm{NiFe} / \mathrm{CN}_{x}$ electrode with a disk scan rate of $5 \mathrm{mV} \mathrm{s}^{-1}$ and a constant ring potential of $1.5 \mathrm{~V}$ (vs. $\mathrm{RHE}$ ) in $\mathrm{O}_{2}$-saturated $0.1 \mathrm{M} \mathrm{KOH}$ at $1600 \mathrm{rpm}$, and (inset) percentage of $\mathrm{HO}_{2}{ }^{-}$and the electron transfer number $(n)$ of $\mathrm{m}-\mathrm{NiFe} /$ $\mathrm{CN}_{x}$ at various potentials; (d) the chronoamperometric response to the addition of methanol at the $\mathrm{m}-\mathrm{NiFe} / \mathrm{CN}_{x}$ and the Pt/C electrodes; (e) the chronoamperometric durability evaluation of $\mathrm{m}-\mathrm{NiFe} / \mathrm{CN}_{x}$ and $\mathrm{Pt} /$ $\mathrm{C}$ at $0.65 \mathrm{~V}$ (vs. RHE) with a rotation speed of $1600 \mathrm{rpm}$.

amount of $\mathrm{H}_{2} \mathrm{O}_{2}$ was produced. Actually, the yield of $\mathrm{HO}_{2}{ }^{-}$at the $\mathrm{m}-\mathrm{NiFe} / \mathrm{CN}_{x}$ electrode was evaluated to be below $16.5 \%$ over the potential range of $0.20-0.80 \mathrm{~V}$, and the electron transfer number was calculated based on $I_{\mathrm{r}}$ and $I_{\mathrm{d}}$ to be 3.6-3.8 (inset of Fig. 8c).

We also compared the $\mathrm{m}-\mathrm{NiFe} / \mathrm{CN}_{x}$ catalyst with a commercial $\mathrm{Pt} / \mathrm{C}$ catalyst for their ORR electrocatalytic performance. Although the $\mathrm{m}-\mathrm{NiFe} / \mathrm{CN}_{x}$ showed a slightly higher onset potential than the Pt/C-modified electrode (Fig. S7 $\dagger$ ), the former manifests at least three distinct advantages over the Pt/C catalyst. First, with the addition of $10 \mathrm{vol} \%$ methanol to the electrolyte, the $\mathrm{m}-\mathrm{NiFe} / \mathrm{CN}_{x}$ displayed a negligible current response, while the $\mathrm{Pt} / \mathrm{C}$ almost decreased by half in current density (Fig. 8d), suggesting that the $\mathrm{m}-\mathrm{NiFe} / \mathrm{CN}_{x}$ shows very good tolerance to the fuel for directed methanol fuel cells, i.e., methanol. Second, the $\mathrm{m}-\mathrm{NiFe} / \mathrm{CN}_{x}$ had greater durability than the Pt/C. The chronoamperometric measurements at $0.65 \mathrm{~V}$ were performed for more than $6 \mathrm{~h}$ to assess their durability (Fig. 8e), which led to less than a $10 \%$ loss of initial current density for the m-NiFe/ $\mathrm{CN}_{x}$, but more than a $25 \%$ loss for the Pt/ C. Third, the m-NiFe/ $\mathrm{CN}_{x}$ also cost less than one-tenth of the commercial $\mathrm{Pt} / \mathrm{C}$ catalysts based on a rough estimate from our experiments.

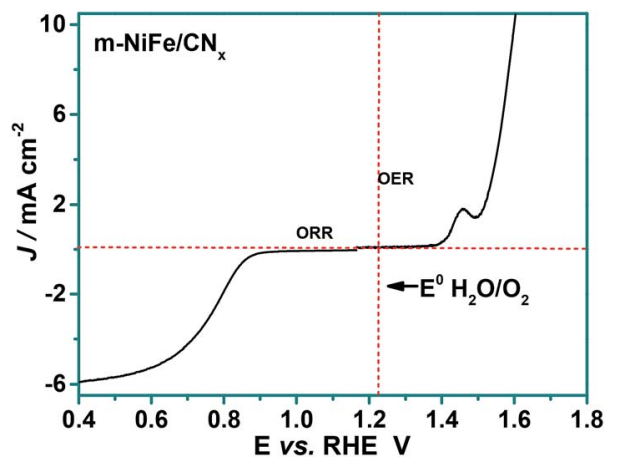

Fig. 9 RDE curves of $\mathrm{m}-\mathrm{NiFe} / \mathrm{CN}_{x}$ hybrid in $\mathrm{O}_{2}$-saturated $0.1 \mathrm{M} \mathrm{KOH}$ at $1600 \mathrm{rpm}$ as bi-functional catalyst for ORR and OER.

The abovementioned results clearly demonstrate that the $\mathrm{m}$ $\mathrm{NiFe} / \mathrm{CN}_{x}$ has a higher activity than Ir/C for OER and possesses attractive advantages over Pt/C for ORR. Activities for OER and ORR were judged by the difference between the potential required to oxidize water at a current density of $10 \mathrm{~mA} \mathrm{~cm}^{-2}$ and for oxygen reduction at a current density of $3 \mathrm{~mA} \mathrm{~cm}{ }^{-2}$. The smaller difference indicates a better performance for a reversible oxygen electrode. By this metric, the $\mathrm{m}-\mathrm{NiFe} / \mathrm{CN}_{x}$ has an oxygen electrode activity of $0.83 \mathrm{~V}$ (Fig. 9). The as-developed m$\mathrm{NiFe} / \mathrm{CN}_{x}$ shows an electrocatalytic activity comparable to that of the $\mathrm{Pt} / \mathrm{C}$ for catalyzing ORR and that of the $\mathrm{Ir} / \mathrm{C}$ catalyst for catalyzing OER, respectively. Moreover, the $\mathrm{m}-\mathrm{NiFe} / \mathrm{CN}_{x}$ outperforms most of the emerging bifunctional electrocatalysts (Tables $\mathrm{S} 1-\mathrm{S} 3 \dagger$ ). Given the fact that the $\mathrm{m}-\mathrm{NiFe} / \mathrm{CN}_{x}$ is costeffective and can be mass produced, the $\mathrm{m}-\mathrm{NiFe} / \mathrm{CN}_{x}$ electrocatalyst is very competitive as the next-generation electrocatalyst for ORR and OER. The following factors can be summarized to elucidate the fundamental aspects of high activity and excellent stability of the $\mathrm{m}-\mathrm{NiFe} / \mathrm{CN}_{x}$ catalyst for both OER and ORR. First, the $\mathrm{m}-\mathrm{NiFe} / \mathrm{CN}_{x}$ inherits the highly ordered porous structure of SBA-15 and has a considerably large surface area while achieving high electrical conductivity; these unique properties are greatly beneficial for accelerating the electron transfer rate and facilitating mass (ions or electrolyte) transportation. In addition, the series of controlled experiments demonstrate that multiple active sites, including doped nitrogen and NiFe-alloy nanoparticles, are uniformly dispersed in the nanochannels of the ordered porous structure, making the catalytic sites readily accessible for electroactive substances and allowing them to synergistically catalyze the OER and ORR with high catalytic activity. Furthermore, the m-NiFe/ $\mathrm{CN}_{x}$ hybrid was produced by annealing at a high temperature, and the active sites were embedded in nanochannels of a porous structure and protected by a layer of nanocarbon. This stable structure explains the excellent stability of the m-NiFe/ $\mathrm{CN}_{x}$ during long-term operation.

\section{Conclusions}

We have successfully developed a simple and convenient method to prepare a conductive mesoporous structure 
supported NiFe-alloy electrocatalyst. The unique features endow $\mathrm{m}-\mathrm{NiFe} / \mathrm{CN}_{x}$ with outstanding electrocatalytic performance for OER and ORR in terms of activity, kinetics, and stability. The low cost and high catalytic activity of $\mathrm{m}-\mathrm{NiFe} / \mathrm{CN}_{x}$, together with simple synthesis and the possibility of mass production, may offer a promising avenue to develop alternative catalysts to Ir-based materials for OER in water splitting systems and to Pt-based substances for ORR in fuel cells or metal-air battery systems.

\section{Acknowledgements}

Financial support for this work was provided by the U.S. Department of Energy (DE-EE0003208), the Research Growth Initiative Program of the University of Wisconsin-Milwaukee (UWM), and the National Natural Science Foundation of China (no. 21206068).

\section{Notes and references}

1 A. J. Bard and M. A. Fox, Acc. Chem. Res., 1995, 28, 141.

2 N. S. Lewis, Science, 2007, 315, 798.

3 J. Suntivich, K. J. May, H. A. Gasteiger, J. B. Goodenough and Y. Shao-Horn, Science, 2011, 334, 1383.

4 Y. Surendranath, M. W. Kanan and D. G. Nocera, J. Am. Chem. Soc., 2010, 132, 16501.

5 J. A. Turner, Science, 2004, 305, 972.

6 M. G. Walter, E. L. Warren, J. R. McKone, S. W. Boettcher, Q. Mi, E. A. Santori and N. S. Lewis, Chem. Rev., 2010, 110, 6446.

7 Z. Wei, J. Sun, Y. Li, A. K. Datye and Y. Wang, Chem. Soc. Rev., 2012, 41, 7994.

8 I. Katsounaros, S. Cherevko, A. R. Zeradjanin and K. J. J. Mayrhofer, Angew. Chem., Int. Ed., 2014, 53, 102.

9 J. Lee, B. Jeong and J. D. Ocon, Curr. Appl. Phys., 2013, 13, 309.

10 J. A. Cracknell, K. A. Vincent and F. A. Armstrong, Chem. Rev., 2008, 108, 2439.

11 S. M. Barnett, K. I. Goldberg and J. M. Mayer, Nat. Chem., 2012, 4, 498.

12 J. B. Gerken, J. G. McAlpin, J. Y. C. Chen, M. L. Rigsby, W. H. Casey, R. D. Britt and S. S. Stahl, J. Am. Chem. Soc., 2011, 133, 14431.

13 M. Gong, Y. Li, H. Wang, Y. Liang, J. Z. Wu, J. Zhou, J. Wang, T. Regier, F. Wei and H. Dai, J. Am. Chem. Soc., 2013, 135, 8452.

14 C. C. L. McCrory, S. Jung, J. C. Peters and T. F. Jaramillo, J. Am. Chem. Soc., 2013, 135, 16977.

15 J. Rosen, G. S. Hutchings and F. Jiao, J. Am. Chem. Soc., 2013, $135,4516$.

16 K. Sun, N. Park, Z. Sun, J. Zhou, J. Wang, X. Pang, S. Shen, S. Y. Noh, Y. Jing, S. Jin, P. K. L. Yu and D. Wang, Energy Environ. Sci., 2012, 5, 7872.

17 B. Iandolo, B. Wickman, B. Seger, I. Chorkendorff, I. Zoric and A. Hellman, Phys. Chem. Chem. Phys., 2014, 16, 1271.

18 L. Dai, Acc. Chem. Res., 2013, 46, 31.
19 K. Gong, F. Du, Z. Xia, M. Durstock and L. Dai, Science, 2009, 323, 760.

20 Y. Li, W. Zhou, H. Wang, L. Xie, Y. Liang, F. Wei, J.-C. Idrobo, S. J. Pennycook and H. Dai, Nat. Nanotechnol., 2012, 7, 394.

21 Y. Liang, Y. Li, H. Wang, J. Zhou, J. Wang, T. Regier and H. Dai, Nat. Mater., 2011, 10, 780.

22 S. Wang, E. Iyyamperumal, A. Roy, Y. Xue, D. Yu and L. Dai, Angew. Chem., Int. Ed., 2011, 50, 11756.

23 W. Wei, H. Liang, K. Parvez, X. Zhuang, X. Feng and K. Muellen, Angew. Chem., Int. Ed., 2014, 53, 1570.

24 Z. Wen, S. Ci, F. Zhang, X. Feng, S. Cui, S. Mao, S. Luo, Z. He and J. Chen, Adv. Mater., 2012, 24, 1399.

25 J. Liang, Y. Zheng, J. Chen, J. Liu, D. Hulicova-Jurcakova, M. Jaroniec and S. Z. Qiao, Angew. Chem., Int. Ed., 2012, 51, 3892.

26 Y. Zheng, Y. Jiao, J. Chen, J. Liu, J. Liang, A. Du, W. Zhang, Z. Zhu, S. C. Smith, M. Jaroniec, G. Q. Lu and S. Z. Qiao, J. Am. Chem. Soc., 2011, 133, 20116.

27 J. D. Baran, H. Gronbeck and A. Hellman, J. Am. Chem. Soc., 2014, 136, 1320.

28 S. Mao, Z. Wen, T. Huang, Y. Hou and J. Chen, Energy Environ. Sci., 2014, 7, 609.

29 J. Xu, D. Aili, Q. Li, E. Christensen, J. O. Jensen, W. Zhang, M. K. Hansen, G. Liu, X. Wang and N. J. Bjerrum, Energy Environ. Sci., 2014, 7, 820.

30 A. J. Bard, J. Am. Chem. Soc., 2010, 132, 7559.

31 G. Zhang, Z.-G. Shao, W. Lu, G. Li, F. Liu and B. Yi, Electrochem. Commun., 2012, 22, 145.

32 K. J. J. Mayrhofer, K. Hartl, V. Juhart and M. Arenz, J. Am. Chem. Soc., 2009, 131, 16348.

33 V. R. Stamenkovic, B. S. Mun, M. Arenz, K. J. J. Mayrhofer, C. A. Lucas, G. Wang, P. N. Ross and N. M. Markovic, Nat. Mater., 2007, 6, 241.

34 J. C. Meier, I. Katsounaros, C. Galeano, H. J. Bongard, A. A. Topalov, A. Kostka, A. Karschin, F. Schueth and K. J. J. Mayrhofer, Energy Environ. Sci., 2012, 5, 9319.

35 J. D. Blakemore, N. D. Schley, M. N. Kushner-Lenhoff, A. M. Winter, F. DSouza, R. H. Crabtree and G. W. Brudvig, Inorg. Chem., 2012, 51, 7749.

36 V. K. Puthiyapura, S. Pasupathi, H. Su, X. Liu, B. Pollet and K. Scott, Int. J. Hydrogen Energy, 2014, 39, 1905.

37 Y. Gorlin, B. Lassalle-Kaiser, J. D. Benck, S. Gul, S. M. Webb, V. K. Yachandra, J. Yano and T. F. Jaramillo, J. Am. Chem. Soc., 2013, 135, 8525.

38 Q. Liu, J. Jin and J. Zhang, ACS Appl. Mater. Interfaces, 2013, $5,5002$.

39 Y. J. Sa, K. Kwon, J. Y. Cheon, F. Kleitz and S. H. Joo, J. Mater. Chem. A, 2013, 1, 9992.

40 D. Wang, X. Chen, D. G. Evans and W. Yang, Nanoscale, 2013, 5, 5312.

41 F.-D. Kong, S. Zhang, G.-P. Yin, J. Liu and A.-X. Ling, Catal. Lett., 2014, 144, 242.

42 Y. Gorlin and T. F. Jaramillo, J. Am. Chem. Soc., 2010, 132, 13612.

43 W. G. Hardin, D. A. Slanac, X. Wang, S. Dai, K. P. Johnston and K. J. Stevenson, J. Phys. Chem. Lett., 2013, 4, 1254. 
44 F. Raimondi, G. G. Scherer, R. Kotz and A. Wokaun, Angew. Chem., Int. Ed., 2005, 44, 2190.

45 J.-I. Jung, H. Y. Jeong, J.-S. Lee, M. G. Kim and J. Cho, Angew. Chem., Int. Ed., 2014, 53, 4582.

46 M. Risch, K. A. Stoerzinger, S. Maruyama, W. T. Hong, I. Takeuchi and Y. Shao-Horn, J. Am. Chem. Soc., 2014, 136, 5229.

47 D. Y. Zhao, J. L. Feng, Q. S. Huo, N. Melosh, G. H. Fredrickson, B. F. Chmelka and G. D. Stucky, Science, 1998, 279, 548-552.
48 A. Fischer, J. O. Mueller, M. Antonietti and A. Thomas, ACS Nano, 2008, 2, 2489.

49 Y.-S. Jun, W. H. Hong, M. Antonietti and A. Thomas, Adv. Mater., 2009, 21, 4270.

50 X.-H. Li and M. Antonietti, Chem. Soc. Rev., 2013, 42, 6593.

51 Y. Shi, Y. Wan, R. Zhang and D. Zhao, Adv. Funct. Mater., 2008, 18, 2436. 